\title{
A Research Model for Enterprise Modeling in ICT-Enabled Process Change
}

\author{
Anniken Karlsen \\ Aalesund University College, \\ Department of Engineering and Maritime Studies, Norway
}

\begin{abstract}
There are few empirical studies and accompanying models of enterprise modeling (EM) practice in information and communication technology (ICT) enabled process change. This paper presents a research model to be used in a project investigating the use of EM in ICT-enabled process change in Norwegian west coast enterprises. Building on categories and sub-categories from the field of process modeling, the model constitutes a wide array of propositions concerning EM practice, thereby evoking various directions of further inquiery.
\end{abstract}

Keywords: ICT-enabled process change, enterprise modeling practice, the PMP study.

\section{Introduction}

According to Persson and Stirna 1], research concerning enterprise modeling practice has been more or less neglected by the research community. Focus has instead been placed on the development of enterprise modeling methods. This matches the situation concerning research into process modeling practice, as emphasized in relation to a study by Eikebrokk et al. 23 named the Process Modelling Practice (PMP) study.

In this paper an enterprise modeling practice (EMP) research model is presented, showing possible categories influencing or being influenced by enterprise modeling. Besides being a research model for this particular project, the EMP model exhibits key factors of importance and interest to anyone engaged in practical ICT enabled process change. The model will be applied in a study of enterprise modeling use in ICT enabled process change. Empirical evidence will be gained through cases concerning enterprises on the west coast of Norway. The EMP study is initiated to supplement the PMP study in an effort to contribute towards a theory of model-based process change. Through reviewing literature on the field, the EMP model is derived from compiling different views and findings from a variety of sources. Since most sources relate their work especially to process modeling practice and not the broader scope of enterprise modeling, it becomes essential to emphasize that the categories and relationships of the EMP model constitute a set of propositions/hypotheses in future enterprise modeling practice research where it is inititally assumed that what yields for process modelling yields for enterprise modeling practice also. 
One faces challenges both in the ICT industry and in and between enterprises implementing new ICT systems to facilitate processes 456/789. Statements emphasize that a large part of implementation failures are related to insufficient alignment between various aspects or parts of an organization and the new technology 1011. Henderson [12, page xiii] says that emphasis on modeling is well chosen because it is shared models of systems that will lead to the common understanding on which rapid progress can be made. The acknowledgement of this view can be seen through the development of different enterprise architectures that has emerged over the past decade; the Zachman Framework for Enterprise Architecture, DoDAF, PERA, CIMOSA, ARIS and GERAM, to mention just a few. In addition, several commercial computer tools have come into the marketplace in recent years to assist with architecture visualization and modeling.

\section{Theory}

\section{$2.1 \quad$ Enterprise Modeling}

Enterprise modeling (EM) is concerned with representing the structure, organization and behavior of a business entity [13], i.e., a part of an enterprise, a group of enterprises cooperating, the whole enterprise or just single processes in the value chain, to evaluate its performances or reengineer its material, information or control flows in order to make it more efficient [1314.

Vernadat 15] defines EM as the set of activities or processes used to develop the various parts of an enterprise model to address some modeling finality, whereas an enterprise model is a consistent set of special-purpose and complementary models describing the various facets of an enterprise to satisfy some purpose of some business users. In this way an enterprise model is not one monolithic model, but an assembly of models [14, for example organization models, process models, data models, configuration models and plant layout models [13.

According to Vernadat [15] an enterprise model already exists in any company, be it small or large. The problem is that in nearly all cases it is poorly formalized. It exists in the form of organization charts established by management, documented operational procedures, regulation texts, and to a large extent in the vast amount of enterprise data (either in databases, knowledge bases, or simply data files) and code of application programs. However, a large part remains in the mind of enterprise people and is not formalized or even documented at all. [15, page 70]. Supporting this view, Kalpic \& Bernus [16] say that it is a well known fact that much of the existing extremely valuable information and knowledge in enterprises is not made explicit, externalized or formalized and is consequently not available for use by other individuals, and sometimes even can be lost for the enterprises.

According to Miller \& Berger [10, enterprise views such as the executive leadership view, the processes view and resources view relate to each other in general, thus giving rise to questions concerning the who, what, where, when, why and how of enterprise which must be answered simultaneously; all views act as constraints on the others. The making of different enterprise models gives us 
the possibility to see and discuss how the different parts (the ICT system, the processes, etc.) are interconnected and interplay. Understanding means not only knowing what elements the enterprise consists of and how they are related from different aspects, but also how the elements work together in the enterprise as a whole [17. Trying to answer all of the questions from a single viewpoint is like trying to explain what an entire house and its contents are by looking through a single window. It seldom provides a complete and accurate answer [10, page 52]. Following this, when using EM in relation to ICT-enabled process change, different stakeholders like ICT specialists, managers, users etc. have a tool, a set of models that might enable them to discuss status quo and future possibilities concerning process changes and their technological implications in a more holistic way. For example they can see how changes in a business process might imply necessary changes in the enterprise ICT systems or how the implementation of an enterprise resource planning (ERP) solution likely results in the need for major changes in business processes. Combining this insight with information about the enterprise vision, values, mission and goals, the different stakeholders get broader perspectives and knowledge about how the parts relate to each other and which framework one has to work within when planning or doing structural changes in processes enabled by ICT. The latter is connected to the special role of the executive leadership view whereby all activities and organizations in the enterprise must somehow align to and sustain.

\section{$2.2 \quad$ ICT-Enabled Process Change}

Today, we see both localized exploitation and internal integration of ICT, together with business process redesign, business network redesign, and business scope redefinition. The consequences of ICT on the design of processes can be summarized as [18]19]:

- elimination of human work from the structured process through automation

- change of the sequence of activities and simultaneous working

- gathering of process information

- integration of tasks leading to the coordination of parts and tasks

- object orientation with the effect of tracking the status of process and work

- optimized analysis increasing the possibilities of analyzing information and decision making

- elimination of interfaces with the effect of reducing critical interdependences in processes

- the overcoming of geographic distances resulting in wide area coordination of processes

Information system (IS) development methodologies are largely dominated by a functionalist perspective, that is, how to produce functionally correct and efficient user requirements, as a basis for system specifications. ICT-enabled process change calls for IS development methodologies whereby the development of computer systems is perceived as an organizational issue, in the tradition of 
sosio-technical systems thinking if one follows Munkvold [20] stating that the development and implementation of information systems can be seen as a special form of organizational change activity and that the mutual relationship between organizations and information technology makes this process sosio-technical by nature. The goal according to the socio-technical perspective is joint optimization of the social and technical systems in an organization [20. Optimization of one of the systems at the expense of the other will only result in sub-optimal solutions. Therefore all organizational design processes should also focus on the quality of work life of the employees, the latter making it important that different stakeholders participate in the design process since it is believed that decisions regarding the specification of work are best made by those who actually perform the tasks [20].

The MUST method 20] for participatory design is an example of a methodological development that has clear link to the socio-technical perspective which speaks for itself concerning enterprise models as "natural ingredients when developing an IS. It is based on the principles of participation, close links to project management, design as a communication process, combining ethnography and intervention, co-development of ICT, work organization and users qualifications and sustainability . The method includes management issues in relation to design processes in an organizational context; something that should be highly valuable considering McAfee's reality description: "'Managers I've worked with admit privately that success with ICT requires their commitment, but they're not clear where, when, and how they should get involved. That's partly because executives usually operate without a comprehensive model of what ICT does for companies, how it can affect organizations, and what managers must do to ensure that ICT initiatives succeed" [7, page 142].

\subsection{The PMP Model}

Iden, Eikebrokk, Olsen \& Opdahl [2 21] emphasize that process change, in various incarnations, has been a central topic in the IS field for several decades. Their study, named the process-modeling practice (PMP) study, give insight into Norwegian model-supported process-change practice, focusing especially on process modeling. As part of their study they introduce The a priori PMP model [22, figure 1, and The Revised PMP model [23, figure 2.

The a priori PMP model indicates that characteristics of the organization (process and modeling maturity) have influence on the modeling process. Furthermore, the model shows that the purpose of modeling as well as the artifacts available influence on the modeling process. Particularly interesting is the suggestion that the modeling process has an outcome not only relevant for the process per se, but influence the organization as a whole in form of eventual process maturity and modeling maturity.

The revised PMP model focuses on how Modelling processes and Process competence are related to the Outcome of model-based process change projects, where Process Modeling competence corresponds to Initial process-modelling maturity in the a priori model and Process-orientation competence corresponds 


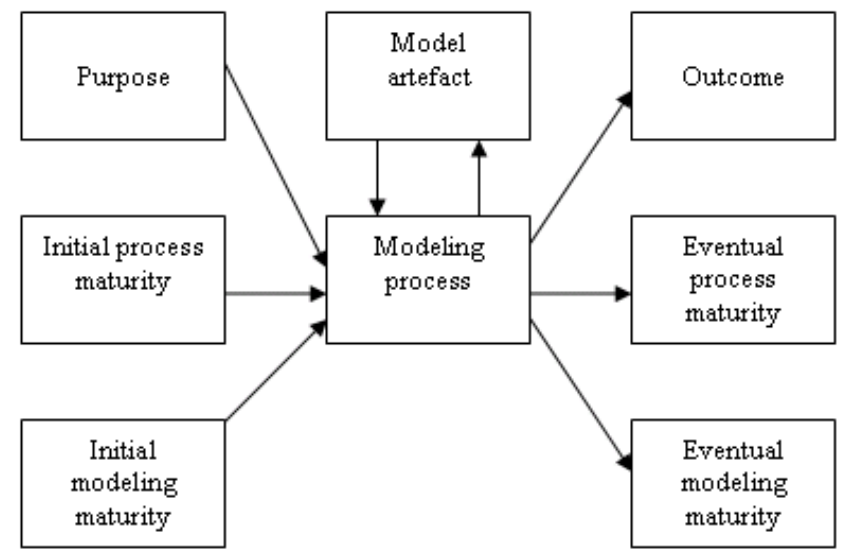

Fig. 1. The a priori PMP model

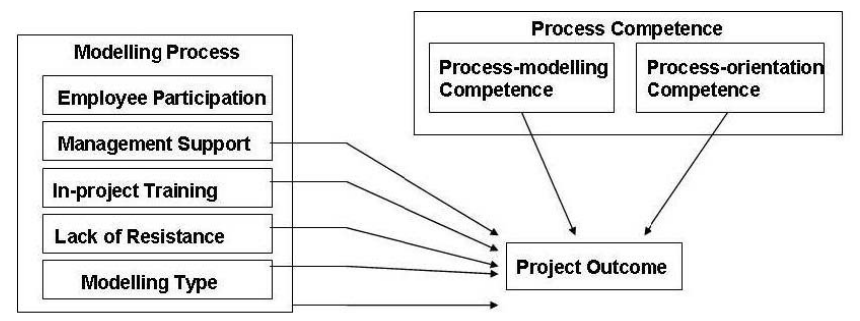

Fig. 2. The revised PMP model

to Initial process maturity in the initial model. The revised model has retained the Modeling process construct in the a priori model; defined as the "activities carried out within the project to improve the organization's processes" [23].

From the initial study the following constructs are kept as dimentions of the modeling process: Employee participation, Management support, In-project training, Lack of resistance and Model type. In the revised model Project outcome is brought in as an main variable decomposed into the dimensions: Goal achievement, Organizational impact, Process-orientation learning and Processmodeling learning [23].

Eikebrokk et al. [23] states that a central hypothesis is confirmed in their study: There is a positive relationship between modeling processes in terms of management support, lack of resistance, in-project training, model types and project outcome.

For short one can sum up that their analysis indicates that a combination of technological (i.e. Model type), social (i.e. Lack of resistance) and organisational factors (i.e. Management support) explain the outcome of model-based 
process-change projects, being aware that their present study cannot exclude the importance of additional dimensions of Modeling process [23].

A motivation for being occupied with modeling in projects is that quantitative and qualitative analysis in the PMP study [3] shows that high-outcome projects tend to have highly complex modeling processes, whereas middle- and low-outcome projects follow simpler processes. Qualitative analysis also indicates that high-outcome projects use more complex model artifacts than middle- and low-outcome projects.

\section{The EMP Research Model}

To conduct a study especially related to ICT-enabled process change projects the EMP model has been developed to be used as a tool in further work. In this section the EMP model is presented. The model incorporates and builds upon the categories and subcategories found in the PMP model [2]3, findings from the PMP study, aspects found in literature, especially in relation to the writings of Davenport [19] and Sedera et al. [24], and a pilot study of a corporate merger case 25. Concerning the EMP model the merger case indicated that the categories project resources, project purpose and systems development methodology might influence on the modelling process, and that outcome of a "'well-conducted"' modeling process might improve user satisfaction through a better match between organizational needs and ICT solution but also through user participation. The findings from the pilot study, which will be further examined, can be found under Context, table 4, in the EMP model. In section 4 the PMP and the EMP study are compared and discussed.

Figure 3 shows the enterprise-modeling practice (EMP) model that has been developed.

The three main categories in the model are Enterprise modeling (EM), Context and Outcome.

Enterprise modeling (EM). EM is defined as the set of activities or processes used to develop the various parts of an enterprise model to address some modeling finality in accordance with Vernadat [15]. This category is the focal point of study; it addresses both the development of new models and the additional usage of existing models in relation to the ICT-enabled process change project. It includes both the usage and making of formalized and non-formalized models, this latter being of interest in accordance with Vernadat [15] saying that to a large extent, models are in the mind of the enterprise people; not being formalized or documented at all. In cases where the enterprise models are just part of the individuals' minds, one should expect that the ability to share insight is reduced, thus giving rise to a sub-optimal ICT-enabled process change solution. EM is further elaborated by sub-categories as shown in table 1, where the column named 'Motivation/Sources' gives references to the sources that motivates the categories and relationships of the EMP model. 


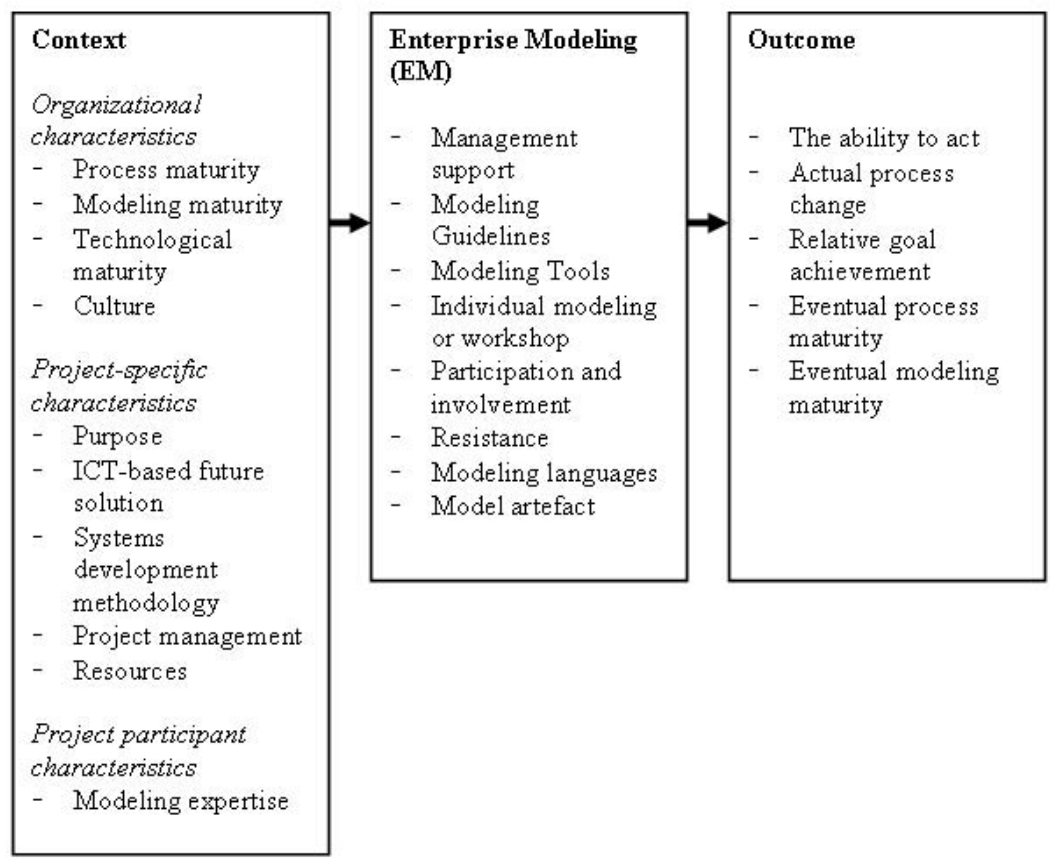

Fig. 3. The EMP model

The sub-categories of the main category Enterprise Modeling are mainly linked to findings from the PMP study, where quantitative analyses [2] show that:

- management support is significantly correlated with outcome

- individual modeling or workshop is correlated with eventual process maturity

- participation and involvement are correlated with outcome

- modeling languages are correlated with modeling framework

- resistance is negatively correlated with model artefact

Sedera et al. 24] among others emphasize the relevance of Modeling Guidelines and Modeling Tools.

Context. Context is defined as the setting of the project comprising organizational characteristics, project specific characteristics and project participant characteristics.

Organizational characteristics is a collective term of those organizational categories that might influence the modeling process. The a priori PMP model points to process maturity and modeling maturity as possible relevant categories.

Project-specific characteristics is a collective term of those categories specific to the project that possibly influence the modeling process. In this category one find sub-categories like ICT-based future solution, Systems development methodology 
Table 1. Enterprise modeling practice; Enterprise Modeling.

\begin{tabular}{ll} 
Category & Definition \\
\hline Management & The level of commitment by manage- \\
Support & ment in the organization to the modeling \\
& project, in terms of their own involvement \\
& and their allocation of valuable organiza- \\
& tional resources. (Adapted from Sedera et \\
& al. 24])
\end{tabular}
Motivation/Sources

\begin{tabular}{|c|c|c|}
\hline $\begin{array}{l}\text { Modeling } \\
\text { Guidelines }\end{array}$ & $\begin{array}{l}\text { A detailed set of instructions that describes } \\
\text { and guides the process of modeling. (Based } \\
\text { on Sedera et al. [24]) }\end{array}$ & Sedera et al. 24] \\
\hline $\begin{array}{l}\text { Modeling } \\
\text { Tools }\end{array}$ & $\begin{array}{l}\text { Software that facilitates the design, main- } \\
\text { tenance and distribution of models. (Based } \\
\text { on Sedera et al. [24]) }\end{array}$ & $\begin{array}{l}\text { Sedera et al. [24], Som- } \\
\text { mar [26], Eikebrokk et } \\
\text { al. 3] }\end{array}$ \\
\hline $\begin{array}{l}\text { Individual } \\
\text { modeling or } \\
\text { workshop }\end{array}$ & $\begin{array}{l}\text { To what extent EM is done as a team-work } \\
\text { or on an individual basis. (Based on Dav- } \\
\text { enport [19]) }\end{array}$ & $\begin{array}{l}\text { Davenport [19] and } \\
\text { Eikebrokk [2] }\end{array}$ \\
\hline $\begin{array}{l}\text { Participation } \\
\text { and involve- } \\
\text { ment }\end{array}$ & $\begin{array}{l}\text { The degree of input from stakeholders, for } \\
\text { the design and approval of the models. } \\
\text { (Based on Sedera et al. [24]) }\end{array}$ & $\begin{array}{l}\text { Eikebrokk et al. 3], } \\
\text { Sedera et al. 24] }\end{array}$ \\
\hline
\end{tabular}

\begin{tabular}{lll}
\hline $\begin{array}{l}\text { Model arte- } \\
\text { fact }\end{array}$ & $\begin{array}{l}\text { A man-made representation of parts of } \\
\text { an enterprise, for example of a process. } \\
\text { (Adapted from Eikebrokk et al. [2]) }\end{array}$ \\
\hline Resistance & $\begin{array}{l}\text { A state of mind reflecting unwillingness or } \\
\text { unreceptiveness. (Adapted from Hultman }\end{array}$ & Eikebrokk et al. [3] \\
& {$[27]$ ) } & \\
\hline $\begin{array}{l}\text { Modeling } \\
\text { languages }\end{array}$ & $\begin{array}{l}\text { The grammar or the syntactic rules of the } \\
\text { selected modeling techniques. }\end{array}$ & Eikebrokk et al. [3] \\
\hline
\end{tabular}

and Project Management, among others. The possible relevance of project-specific characteristics to EM might be indicated by the research of Sedera, Gable, Rosemann and Smyth 24, where Project Management was the most cited success factor in relation to process modeling across all three case studies.

Project participant characteristics are characteristics of those involved in the ICT-enabled process change project. It is singled out as a special category in the research model. In contrast, research on the PMP model does not have this perspective as an embedded unit of analysis. In conjunction with this category it can be mentioned that findings from the research of Sedera et al. 24] suggest that experiences with conceptual modeling is related to success in process modeling, indicating a possible relationship in the EMP model.

Each (sub-) category is further elaborated by sub-categories as shown in table 2, 3 and 4, where table 2 shows sub-categories of organizational characteristics in Context, table 3 shows sub-categories of project participant characteristics in 
Context, and table 4 shows sub-categories of project-specific characteristics in Context.

The sub-categories of the main category Context can be linked to different sources. For example are Process maturity and Modeling Maturity known from the PMP study, where qualitative analysis indicates weak patterns between high initial process maturity and modeling maturity, and weak patterns between high initial process maturity and modeling maturity. Sedera et al. 24] make clear the importance of culture, modeling expertise, and project management in their work, whilst for example technological maturity is associated with Davenport 19 stating that knowledge of existing solutions implies possible restrictions on the process design and that knowledge of possible future solutions might influence how processes are shaped.

Outcome. Outcome is defined as the phenomena that follow and are caused by EM, including attainment of purpose and the effect of EM on the ICT-enabled process change project solution. This category relates to the outcomes expected

Table 2. Enterprise modeling practice; Context; Organizational characteristics

\begin{tabular}{llll} 
Category & Definition & Motivation/Sources \\
\hline $\begin{array}{l}\text { Process ma- } \\
\text { turity }\end{array}$ & $\begin{array}{l}\text { An organization's capability for pro- } \\
\text { cess management and operation, including } \\
\text { available competence and current practice. }\end{array}$ & \\
& (Adapted from Eikebrokk et al. [2]) & \\
\hline $\begin{array}{l}\text { Modeling } \\
\text { maturity }\end{array}$ & $\begin{array}{l}\text { An organizations capability for EM, in- } \\
\text { cluding available competence and current }\end{array}$ & Eikebrokk et al. [2] \\
& practice. (Adapted from Eikebrokk et al. & \\
\hline Technological & An organizations capability within the & Davenport [19] \\
maturity & field of ICT; knowledge of existing solu- & \\
& tions and knowledge of possible future or & \\
& other enterprises solutions. (Based on Dav- & \\
\hline enport [19]) & & \\
\hline Culture & The organizational readiness to accept and & Sedera et al. [24] \\
& participate in a modeling initiative. (Based & \\
& on Sedera et al. 24]) & \\
\hline
\end{tabular}

Table 3. Enterprise modeling practice; Context; Project participant characteristics

\begin{tabular}{lll} 
Category & Definition & Motivation/Sources \\
\hline $\begin{array}{l}\text { Modeling } \\
\text { expertise }\end{array}$ & $\begin{array}{l}\text { The experiences of the project participants } \\
\text { in terms of conceptual modeling in general. } \\
\text { (Adapted from Sedera [24]) }\end{array}$ & Sedera et al. [24], RAE \\
\hline
\end{tabular}


Table 4. Enterprise modeling practice; Context; Project-specific characteristics Category Definition Motivation

\begin{tabular}{lll} 
Category & Definition & Motivation/Sources \\
\hline Purpose & $\begin{array}{l}\text { The purpose of the ICT-enabled process } \\
\text { change project }\end{array}$ & $\begin{array}{l}\text { Pilot study of corpo- } \\
\text { rate merger }\end{array}$ \\
\hline $\begin{array}{l}\text { ICT-based } \\
\text { future solu- } \\
\text { tion }\end{array}$ & $\begin{array}{l}\text { Mean to enable process change. (Based on } \\
\text { Davenport [19]) }\end{array}$ & Davenport [19] \\
\hline $\begin{array}{l}\text { Systems de- } \\
\text { velopment }\end{array}$ & $\begin{array}{l}\text { A standard process followed in an organi- } \\
\text { zethodol- }\end{array}$ & $\begin{array}{l}\text { Pilot study of conduct all the steps necessary } \\
\text { to rate merger }\end{array}$ \\
ogy & tain information systems [29]. & \\
\hline $\begin{array}{l}\text { Project } \\
\text { manage- }\end{array}$ & $\begin{array}{l}\text { A controlled process of initiating, plan- } \\
\text { ning, executing and closing down a project }\end{array}$ & Sedera et al. [24] \\
\hline ment & {$[29]$.} & \\
\hline Resources & $\begin{array}{l}\text { Available time, money and people to initi- } \\
\text { ate, plan, execute and close down a project }\end{array}$ & rate merger \\
& {$[29]$.} & \\
\hline
\end{tabular}

Table 5. Enterprise modeling practice; Outcome

\begin{tabular}{|c|c|c|}
\hline Category & Definition & Motivation/Sources \\
\hline $\begin{array}{l}\text { The ability } \\
\text { to act }\end{array}$ & $\begin{array}{l}\text { Knowledge; ones capacity to set something } \\
\text { in motion. Nico Stehr } 30\end{array}$ & $\begin{array}{l}\text { Henderson [12, page } \\
\text { xiii] }\end{array}$ \\
\hline $\begin{array}{l}\text { Actual pro- } \\
\text { cess change } 1\end{array}$ & $\begin{array}{l}\text { The effect of EM on processes. (Adapted } \\
\text { from Eikebrokk et al. } 3 \text { ) }\end{array}$ & $\begin{array}{l}\text { Miller and Berger } 10 \\
\text { and Vernadat } 15\end{array}$ \\
\hline $\begin{array}{l}\text { Relative } \\
\text { goal } \\
\text { achieve- } \\
\text { ment }\end{array}$ & $\begin{array}{l}\text { The result of the project seen in accor- } \\
\text { dance with overarching business objectives } \\
\text { (cost reduction, time elimination and so } \\
\text { forth). (Based on Davenport [19]) }\end{array}$ & Eikebrokk et al. 3] \\
\hline $\begin{array}{l}\text { Eventual } \\
\text { process } \\
\text { maturity }\end{array}$ & $\begin{array}{l}\text { Changes in an organizations capability for } \\
\text { process management and operation, in- } \\
\text { cluding available competence and current } \\
\text { practice after the modeling process. (Based } \\
\text { on the PMP study } 2[213]\end{array}$ & Eikebrokk et al. 3 \\
\hline $\begin{array}{l}\text { Eventual } \\
\text { modeling } \\
\text { maturity }\end{array}$ & $\begin{array}{l}\text { Changes in an organizations capability for } \\
\text { EM including available competence and } \\
\text { current practice after the modeling pro- } \\
\text { cess. (Adapted from Eikebrokk[2] }\end{array}$ & Eikebrokk et al. 33 \\
\hline
\end{tabular}

as a result of EM; building upon the PMP project which suggests that the modeling process has an outcome not only relevant for the process per se, but influences the organization as a whole in form of eventual process maturity and 
modeling maturity. Outcome is further elaborated by sub-categories as shown in table 5. These sub-categories are mainly linked to the PMP model revised. Concerning the term "The ability to act" it is chosen after being inspired by Nico Stehr 30]. In itself the term points to one of the most important reasons for making enterprise models in the first place.

\section{Discussion}

The EMP study is initiated to supplement the PMP study looking into modelsupported process-change practice. Based on this it seems sensible to let the EMP model build extensively on the PMP model, concerning categories, definitions and motivations, thereby making findings from the two studies comparable. At the same time there are fundamental differences concerning the model build-up and scope of modeling practice research between the PMP and the EMP study.

First of all, the PMP study focuses on process modeling in process change. The EMP study has a wider perspective; looking into the making of enterprise models in general in conjunction with process change enabled by ICT. This broader scope is the result of a specific interest in ICT projects and why they fail. It is not enough to just look into the alteration of job practices when involved in ICT projects; it is important to have a holistic view of business and the processes concerned if the ICT system is to achieve the intended outcome [28]. Whilst the EMP model to a large degree incorporates the categories of the PMP model, it additionally incorporates elements from literature and the pilot study that has not been a matter of concern in the PMP study, thereby widen the scope of the model. This especially relates to project-specific characteristics, but other sub-categories can also be found, for example technological maturity in organizational characteristics.

The EMP study is in addition focused on gaining information from different stakeholders involved in the same projects, for example in projects related to supply chain management (SCM); where ICT impacts on the interrelationship between flows of goods and flows of information, as well as interrelationships between different business units.

Whereas the PMP project selected process change projects within an array of different sectors from all over Norway, the EMP study will mainly look into the furniture, the marine, and the maritime sector. These are clusters that to a large degree are situated on the west coast of Norway, far from their markets, and that compete on a global basis. Focusing on these three clusters might very well turn out to be valuable to the EM practice study. For example, there might be sector differences that turn out to influence degree of modeling and there might also turn up some cultural factors that are interesting.

While the PMP study focuses on projects where it is known or highly expected to have been conducted modeling, the EMP study will open up for cases where modeling is weakly present or even completely omitted. As seen from the corporate merger case these instances might also reveal interesting relationships. 
In general one can say that the scope of further work on EM in ICT-enabled process change directs the EMP research project to focus on potentially complex change processes, with a high degree of organizational impact, cross functional and cross organizational implications and involvement. Persson [31] e.g. emphasizes a wide array of situational factors influencing the quality of enterprise models that moderate the final outcome of an EM process.

\section{Concluding Remarks and Further Work}

The overall research question for this EMP study is: "How is enterprise modeling used and how can it be used as a technique for IT enabled process change in Norwegian West Coast enterprises?"

The EMP research model constitutes a wide array of propositions/hypotheses concerning EM practice, thereby evoking various directions of inquiery. Examples of relevant questions that can be drawn from the model are:

- For what purposes are EM used in ICT-enabled process change?

- How does the purpose of the modeling affect how the modeling process is carried out?

- How is the modeling process affected by the level of initial process-, and modeling maturity?

- Does more elaborate modelling processes tend to produce and use more complex model artefacts and vice versa?

Having developed a reseach model, I will now turn to current practice in companies on the west coast of Norway, focusing on what is modeled and why, when and how modeling is done during the ICT-enabled process change project. Herein it is interesting to see to what extent complexity and uncertainty associated with model-making in general influence to what extent enterprise models are used and where they are used within ICT -enabled process change.

\section{References}

1. Persson, A., Stirna, J.: Why Enterprise Modelling? An Explorative Study into Current Practice. In: Dittrich, K.R., Geppert, A., Norrie, M.C. (eds.) CAiSE 2001, vol. 2068, p. 465. Springer, Heidelberg (2001)

2. Eikebrokk, T., Iden, J., Olsen, D., Opdahl, A.: In Process Modelling Practice: Theory Formulation and Preliminary Results, NOKOBIT, Molde, Norway (2006)

3. Eikebrokk, T.R., Iden, J., Olsen, D., Opdahl, A.L.: Exploring process-modelling practice: Towards a conceptual model. In: Proceedings of the 41st Hawaii International Conference on System Sciences (2008)

4. Carr, N.: IT Doesn't Matter, May 2003, pp. 41-49. Harvard Business Review (2003)

5. Davenport, T., Short, J.: The New Industrial Engineering: Information Technology and Business Process Redesign, pp. 11-27. Sloan Management Review (Summer 1990)

6. Hammer, M.: Reenginering Work: Don't Automate, Obliterate. Harvard Business Review, pp. 104-112 (July-August 1990) 
7. McAfee, A.: Mastering the Three Worlds of Information Technology, pp. 141-149. Harvard Business Review (November 2006)

8. Smith, H., Fingar, P.: Business Process Management: The Third Wave. MeghanKiffer Press, FL, USA (2003)

9. Smith, H., Fingar, P.: IT Doesn't Matter - Business Processes Do: A Critical Analysis of Nicholas Carr's I.T. Article in the Harvard Business Review. Meghan-Kiffer Press, FL, USA (2003)

10. Miller, T., Berger, D.: Totally Integrated Enterprises: A Framework and Methodology for Business and Technology Improvement. In: Raytheon Professional Services LLC, St. Lucie Press (2001)

11. Wognum, N.: Editorial/Enterprise modelling and system support. Advanced Engineering Informatics 18, 191-192 (2004)

12. Bustard, D., Kawalek, P., Norris, M.: Systems Modeling for Business Process Improvement. Artech House Publishers, Boston (2000)

13. Berio, G., Vernadat, F.: Enterprise modelling with CIMOSA: functional and organizational aspects. Production Planning and Control 12(2), 128-136 (2001)

14. Vernadat, F.: Enterprise Modelling: Objectives, constructs \& ontologies. In: Tutorial held at the EMOI-CAiSE Workshop, Riga, Latvia (June 2004)

15. Vernadat, F.B.: Enterprise Modeling and Integrations, principles and applications. Chapman \& Hall, London (1996)

16. Kalpic, B., Bernus, P.: Business process modelling in industry - the powerful tool in enterprise management. Computers in Industry 47, 299-318 (2001)

17. Kirikova, M.: Explanatory capability of enterprise models. Data and Knowledge Engineering 33, 119-136 (2000)

18. Seidlmeier, H.: Process Modeling With ARIS: A practical Introduction. GWVVieweg (2004)

19. Davenport, T.: Process innovation: reenginering work through information technology. Harvard Business School Press, Boston (1993)

20. Munkvold, B.: Tracing the Roots: The Influence of Socio-Technical Priciples on Modern Organisational Change Practices. In: Coakes, E., Willis, D., Lloyd-Jones, R. (eds), Springer, London (2000)

21. Iden, J., Eikebrokk, T., Olsen, D., Opdahl, A.: In Prosessforbedring - en vurdering av nasjonal praksis, Universitetet i Bergen, Institutt for informasjons- og medievitenskap, Publikasjon, NOKOBIT, vol. 61, pp. 147-164 (2005)

22. Iden, J., Olsen, D., Eikebrokk, T., Opdahl, A.L.: Process change projects: a study of Norwegian practice. In: Proceedings of ECIS, Gotenburg, Sweden, pp. 1671-1682 (2006)

23. Eikebrokk, T., Iden, J., Olsen, D., Opdahl, A.L.: Toward a model of processmodelling practice: Quantitative validation and results. In: Proceedings of ECIS (2008)

24. Sedera, W., Gable, G., Rosemann, M., Smyth, R.: A success model for business process modeling: findings from a multiple case study. In: Proceedings Eight Pacific Asia Conference on Information Systems, Shanghai, China, pp. 485-498 (2004)

25. Karlsen, A., Engelseth, P.: Corporate merger and developing information connectivity in a pelagic fish network - a case study. In: Proceedings of the 8th International Conference on Management in Agri-Food Chains and Networks, Ede, The Netherlands (2008)

26. Sommar, R.: Business process modelling introduction, tutorial, developed by KTH (2006) 
27. Hultman, K.: Managing Resistance to Change. Encyclopedia of Information Systems, USA, vol. 3. Elsevier Science, Amsterdam (2003)

28. RAE, BCS: The Royal Academy of Engineering and the British Computer Society, The Challenges of Complex IT Projects (2004)

29. Hoffer, J., George, J., Valacich, J.: Modern Systems Analysis and Design. Pearson Education, Inc., US (2005)

30. Stehr, N.: The Fragility of Modern Societies: Knowledge and Risk in the Information Age. SAGE Publications, London (2001)

31. Persson, A.: Enterprise modelling in practice: Situational factors and their influence on adopting a participative approach, Ph.D. Thesis. Stockholm University, Report series no. 01-020 (2001); ISSN 1101-8526 